Endocrinol. Japon. 1975, 22 (5), 379 387

\title{
A Receptor Site for Prolactin in Lactating Mouse Mammary Tissues
}

\author{
Senkiti SAKAI, Kaoru KOHMOTO and Tetsu JOHKE* \\ Department of Animal Breeding, Faculty of Agriculture, University \\ of Tokyo, Tokyo 113 and *Department of Physiology, National \\ Institute of Animal Industry, Chiba City, Chiba 280
}

\section{Synopsis}

Prolactin iodinated by lactoperoxidase method showed immunologically, electrophoretically and biologically similar properties to native prolactin and possessed enough specific radioactivity for receptor studies. ${ }^{125}$ I-prolactin was incubated with mouse mammary tissues at 8 days of lactation. Both binding and release of ${ }^{125} \mathrm{I}-$ prolactin depended on incubation time and temperature and were maximal at $37^{\circ} \mathrm{C}$. Michaelis constant was estimated to be $1.4 \times 10^{-9} \mathrm{M}$ from Lineweaver-Burk plot and to be $1.2 \times 10^{-9} \mathrm{M}$ from mid-value of the dose-response curve for displacement with native prolactin. Total number of binding sites for prolactin was $1.38 \times 10^{-15}$ mole per $\mathrm{mg}$ weight of tissue. Ovine prolactin, human growth hormone and human placental lactogen competed with ${ }^{125} \mathrm{I}$-prolactin and dose-response curves for these three hormones were all parallel. These results suggest the existence of a specific receptor site with high affinity for prolactin in lactating mouse mammary glands.

Properties of specific receptor sites for peptide hormones in target organs are being clarified by means of radioiodinated hormones including gonadotropins (Lee and Ryan, 1971 ; Catt et al., 1972; Bralla and Reichert, 1974). Peptide hormones are generally understood to interact with cell membranes. Prolactin has major mammogenic, lactogenic and galactopoietic effects on the mammary gland (Cowie and Tindal, 1971). Recent studies suggested the existence of receptor sites specific to prolactin in the subcellular particle fraction containing cell membrane of mammary glands in mice (Frantz et al., 1974) and in rabbits (Shiu and Friesen, 1974). Chemical properties of receptors are investigated best with isolated molecules; however, at present particle fractionation still requires improve-

$\overline{\text { Received for publication January 7, }} 1975$. ment. In any case, some properties of binding sites can be investigated in situ. The present study was carried out to give some information on the interaction between prolactin and mouse mammary glands using tissue slices. Highly radioactive prolactin which also maintains biological activity was prepared by lactoperoxidase method (Frantz and Turkington, 1972; Shiu et al., 1973).

\section{Materials and Methods}

\section{Iodination of prolactin}

Lactoperoxidase method by Frantz and Turkington (1972) was modified as described below to iodinate prolactin. The reactants were added to a polystyrene tube $(10 \times 75 \mathrm{~mm})$ with microsyringes in the following order and amounts at $20^{\circ} \mathrm{C}$, (1) $500 \mu \mathrm{Ci} \mathrm{Na}{ }^{125} \mathrm{I}$ (Carrier free, New England Nuclear Corporations, U.S.A.) in $10 \mu l 0.1 \mathrm{~N} \mathrm{NaOH,} \mathrm{(2)} 25 \mu l .0 .5 \mathrm{M}$ phosphate buffer (pH 6.9), (3) $5 \mu \mathrm{g}$ prolactin (NIH-P-S9) 
in $10 \mu l 0.05 \mathrm{M}$ phosphate buffer (pH 7.3), and (4) $5 \mu \mathrm{g}$ lactoperoxidase (Calbiochem, U.S.A.) in $5 \mu l 0.05$ $\mathrm{M}$ phosphate buffer ( $\mathrm{pH}$ 7.3). The reaction was started by adding $10 \mu l 0.00025 \%$ hydrogen peroxide. To maintain the reaction, $10 \mu l$ of hydrogen peroxide was added 3 times at 1,3 and 6 minutes. At 10 minutes, the mixture was diluted with $500 \mu l 0.05 \mathrm{M}$ phosphate buffer ( $\mathrm{pH}$ 7.3), and was layered on a $1 \times 17 \mathrm{~cm}$ column of Sephadex G-75 (Pharmacia, Sweden) previously washed with $1 \mathrm{ml}$ of $4 \%$ bovine serum albumin (Fraction V, Daiichi Pure Chemicals, Tokyo) in $0.05 \mathrm{M}$ phosphate buffer ( $\mathrm{pH} 7.3$ ) and equilibrated with the phosphate buffer. Aliquots of $1 \mathrm{ml}$ were collected in tubes containing $0.2 \mathrm{ml}$ of $4 \%$ bovine serum albumin (Fraction V), and counted in a curiemeter (IGC-1B, Aloka, Tokyo). Specific activity of iodinated prolactin was calculated by the method of Greenwood et al. (1961). Radioiodinated prolactin was stored in ice bath until it was used for experiments.

\section{Properties of radioiodinated prolactin Immunoreactivity}

Immunoreactivity was tested using the system of double antibody radioimmunoassay previously reported by Johke (1969). One-tenth $\mathrm{m} l$ of various concentrations of prolactin, $0.1 \mathrm{ml}$ of ${ }^{125} \mathrm{I}$-prolactin $(1.0 \mathrm{ng})$ and $0.1 \mathrm{ml}$ of the guinea-pig antiprolactin serum $(1: 100000)$ were added to $0.5 \mathrm{~m} l$ of diluent consisted of $0.5 \mathrm{M}$ barbital buffer ( $\mathrm{pH}$ 8.6) containing $0.5 \%$ bovine serum albumin, $0.01 \mathrm{M}$ EDTA and $0.01 \%$ merthiolate. After incubation for 4 days at $4^{\circ} \mathrm{C}, 0.1$ $\mathrm{ml}$ of antisera to guinea-pig gamma globulin $(1: 15)$ and $0.1 \mathrm{~m} l$ of normal guinea-pig serum $(1: 250)$ were added to the mixture and incubation was continued for 1 day at $4^{\circ} \mathrm{C}$. The radioactivity of the mixtures was counted in a well-type automatic gamma counter (Nuclear Chicago 4218). Then they were centrifuged at 3000 r.p.m. for 20 minutes at $4^{\circ} \mathrm{C}$ and the supernatants were discarded. The radioactivity of precipitates was counted in the same way and the ratio of the radioactivity of precipitates to the total radioactivity was calculated.

\section{Acrylamide gel disc electrophoresis}

Aliquots of radioiodinated prolactin $(1250 \mathrm{cpm})$ were subjected to $10 \%$ acrylamide gel disc electrophoresis at $\mathrm{pH}$ 9.5. Gels were fixed in $7 \%$ acetic acid after electrophoresis and cut into $2 \mathrm{~mm}$ segments. Each segment was counted in a well-type automatic gamma counter. Ten $\mu \mathrm{g}$ of native prolactin was simultaneously subjected to disc electrophoresis to examine its mobility. The gel was stained in amido black 10B.

\section{Pigeon crop-sac assay}

Pigeon crop-stimulating activity was tested by the method of Tanabe et al. (1954). Five pigeons were injected intradermally with standard prolactin (NIH-
P-S9) totaling $2.67 \mu \mathrm{g}$ per bird on one side of cropsac region once a day for 4 days. Iodinated prolactin was injected in the same way on the contralateral side. The dose of the iodinated prolactin was estimated from radioactivity. On the 5th day responsive areas of crop sac were measured by a planimeter, and the ratio of the area reacting to iodinated prolactin to the area reacting to standard prolactin was calculated.

Binding of ${ }^{125}$ I-prolactin to tissue slices of lactating mouse mammary gland

The thoracic third mammary glands from dd strain mice at 8 days of lactation, killed by cervical dislocation after 5 hours of removal of litters followed by 1 hour of suckling unless otherwise stated, were cut into $0.5-\mathrm{mm}$ thick slices by a tissue slicer (Hotta Rika, Tokyo). Two or three slices $(10$ to $25 \mathrm{mg}$ ) were added to a glass test tube $(18 \times 110 \mathrm{~mm})$ containing $1.5 \mathrm{ml}$ of Medium 199 (Difco, U.S.A.) immediately before incubation. The medium contained $0.5 \%$ bovine serum albumin (crystalized, Miles, U.S.A.) to prevent prolactin from adsorption to glass wall. Six $\mathrm{ng} / \mathrm{m} l{ }^{125} \mathrm{I}$-prolactin and on occasion, test substances were added and equilibrated at $\mathrm{pH} 7.4$ with moistened $95 \% \mathrm{O}_{2} / 5 \% \mathrm{CO}_{2}$ gas. The test tubes were placed in a water bath at 0,20 or $37^{\circ} \mathrm{C}$ and shaken at 100 strokes per minute. At the end of incubation, tissues were washed in three changes of physiological saline, blotted on filter paper, and weighed on a torsion balance. Radioactivity was measured in a well-type automatic gamma counter $30 \%$ counting efficiency. To investigate release of radioactivity, tissues were preincubated in the medium containing ${ }^{125} \mathrm{I}$-prolactın at $37^{\circ} \mathrm{C}$ for 60 minutes as described above and then transferred into the medium without ${ }^{125}$ I-prolactin; incubation was continued at 0,25 or $37^{\circ} \mathrm{C}$. Radioactivity of tissues was counted as described above.

Nonspecific uptake and release of radioactivity were investigated by substituting ${ }^{131} \mathrm{I}$-human serum albumin (Dainabot Radioisotope Laboratory, Tokyo) for ${ }^{125} \mathrm{I}$-prolactin. Tissues were incubated at 0,20 or $37^{\circ} \mathrm{C}$ for up to 120 minutes in the medium containing ${ }^{131}$ I-human serum albumin, or 60 minutes in non-radioactive medium after 60 minutes of preincubation with radioactive albumin at the same temperature.

Acid precipitability of accumulated ${ }^{125}$ I was also tested. Ten slices of mammary tissue incubated for 120 minutes in $3 \mathrm{ml}$ Medium 199 were homogenized in $0.5 \mathrm{ml} 0.9 \%$ saline containing $0.5 \%$ bovine serum albumin (BSA) using glass homogenizer. The homogenate was mixed with $0.5 \mathrm{ml}$ of $10 \%$ trichloracetic acid (TCA) and centrifuged at 2000 r.p.m. for 10 minutes. The incubation medium was also treated with equal volume of $10 \%$ TCA.

Hormones tested for competition with prolactin were ovine growth hormone (NIH-GH-S9), ovine LH 
(NIH-LH-S16), human growth hormone (NIH-GHHS1394), human placental lactogen (NIH), hCG (Sankyo Zoki, Tokyo), pregnant mare serum gonadotropin (Sankyo Zoki), bovine TSH (Armour, U.S.A.), bovine ACTH (Armour) and bovine insulin (Novo, Denmark).

\section{Results}

\section{Properties of iodinated prolactin}

Specific radioactivity of iodinated prolactin was 70 to $90 \mu \mathrm{Ci} / \mu \mathrm{g}$ in 8 experiments of iodination. We assume that $90 \%$ of prolactin was radioiodinated. The recovery of prolactin in a subsequent gel filtration on Sephadex G-75 was $75 \%$ by measuring radioactivity. The presence of dose-response displacement with variousa mounts of native prolactin (Fig. 1) indicates immunological intactness of the iodinated prolactin. Excess antibody precipitated $92.5 \%$ of radioactivity.

When radioiodinated prolactin $(1250 \mathrm{cpm})$ was analysed on $10 \%$ acrylamide gel electrophoresis run at $\mathrm{pH} 9.5$, a radioactive

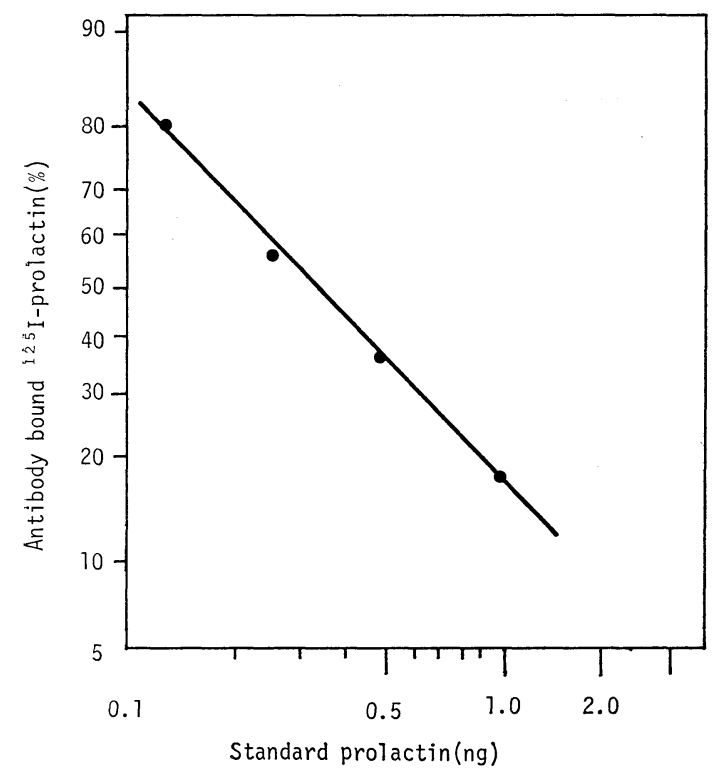

Fig. 1. Standard curve for radioimmunoassay of ovine prolactin using prolactin iodinated by lactoperoxidase method. peak was observed at the same position as the main band of ovine prolactin $(10 \mu \mathrm{g})$ was present on the control gel (Fig. 2).

Pigeon crop-sac assay of iodinated prolactin showed a biological activity similar to that of contralateral control of native prolactin. Mucosa of crop sac injected with iodinated prolactin appeared to be typical reaction to prolactin. Iodinated prolactin was estimated to have $1.112 \pm 0.098(\mathrm{M} \pm$ S.E.) times the potency of native prolactin.

Binding of ${ }^{125}$ I-prolactin to lactating mammary gland: Precipitability of accumulated ${ }^{125}$ I

When TCA was added to the medium before and after incubation without tissues, for 120 minutes, $98.4 \%$ and $98.2 \%$ of radioactivity were precipitable, respectively

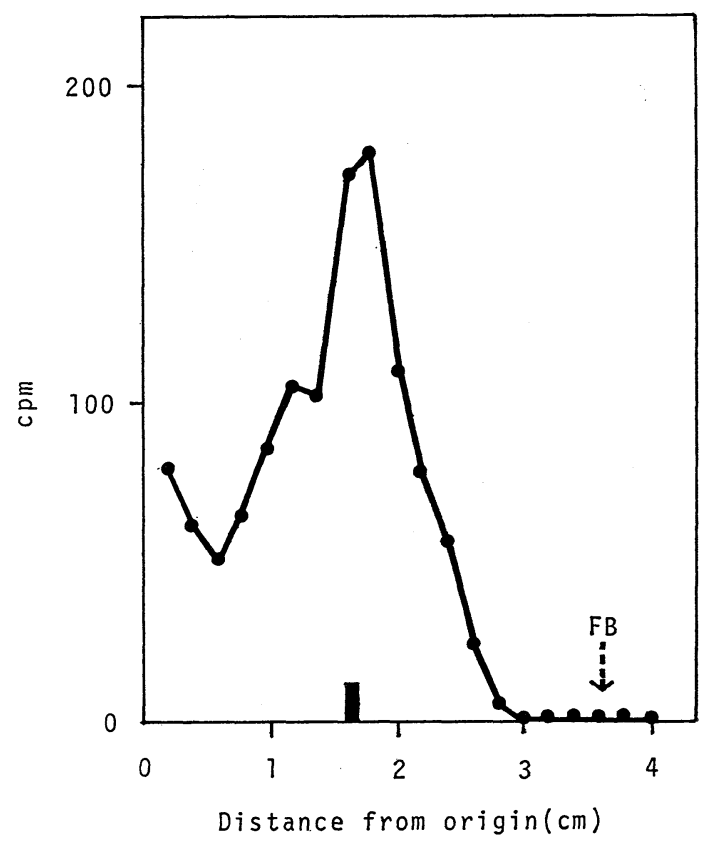

Fig. 2. Radioactivity distribution of ${ }^{125} \mathrm{I}$-prolactin in a $10 \%$ polyacrylamide gel after electrophoresis. The black bar represents the main band of native prolactin stained in $1 \%$ amido black in $7 \%$ acetic acid solution after electrophoresis at the same condition. FB: ion front. 
(Table 1). Medium incubated with tissues precipitated $94.8 \%$ of radioactivity. After incubation, only $84.1 \%$ of ${ }^{125} \mathrm{I}$ in tissue homogenate was present in the precipitant.

Table 1. Radioactivity of incubation media and of mammary tissue precipitated by TCA

\begin{tabular}{|c|c|c|c|}
\hline & $\begin{array}{l}\text { Total } \\
(\mathrm{cpm})\end{array}$ & $\begin{array}{c}\text { Supernatant } \\
(\mathrm{cpm})\end{array}$ & $\begin{array}{c}\text { Precipitation } \\
(\%)\end{array}$ \\
\hline $\begin{array}{l}\text { Medium at } 0 \text { hour } \\
\text { without tissue }\end{array}$ & 136889 & 2219 & 98.4 \\
\hline $\begin{array}{l}\text { Medium after } 2 \\
\text { hours of incubation } \\
\text { without tissue }\end{array}$ & 140921 & 2588 & 98.2 \\
\hline $\begin{array}{l}\text { Medium after } 2 \\
\text { hours of incubation } \\
\text { with tissue }\end{array}$ & 121779 & 6370 & 94.8 \\
\hline $\begin{array}{l}\text { Tissue after } 2 \text { hours } \\
\text { of incubation }\end{array}$ & 2310 & 366 & 84.1 \\
\hline
\end{tabular}

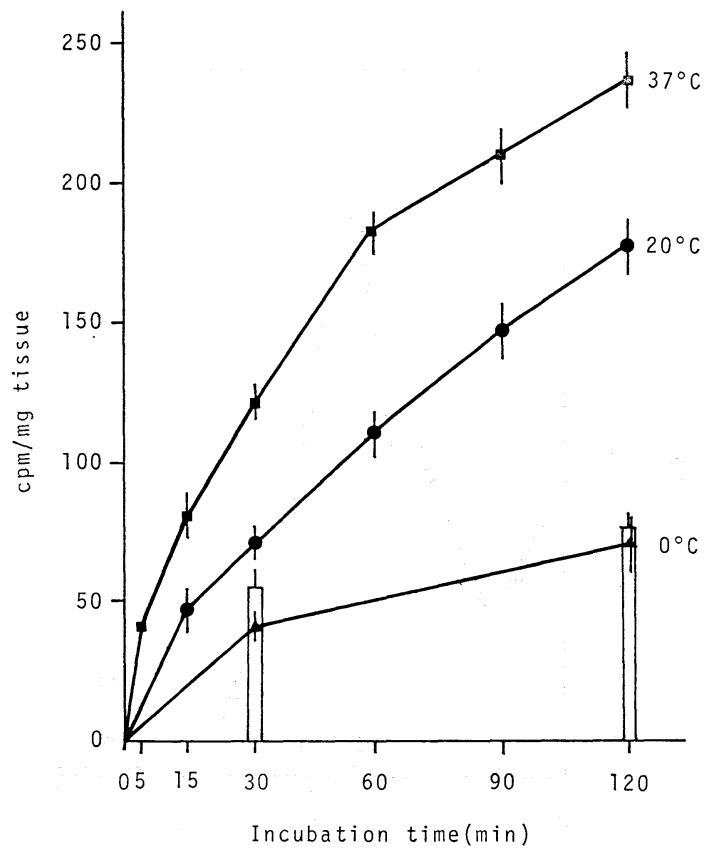

Fig. 3. Radioactivity uptake by mammary tissues during incubation with $6 \mathrm{ng} / \mathrm{ml}$ of ${ }^{125} \mathrm{I}$-prolactin at 0,20 and $37^{\circ} \mathrm{C}$. The two columns show radioactivity in tissues incubated with $5 \mu \mathrm{g} / \mathrm{ml}$ of native prolactin and $6 \mathrm{ng} / \mathrm{ml}$ of ${ }^{125} \mathrm{I}$-protactin at $37^{\circ} \mathrm{C}$ for 30 and 120 minutes. The bars show standard errors of six experiments.
Uptake and release of radioactivity by mammary tissues and influence of temperature

When mammary tissues were incubated with $6 \mathrm{ng} / \mathrm{m} l$ 125 I-prolactin, radioactivity uptake by tissue increased with incubation time. The tissue did not show sharp increase in the accumulation of radioactivity when incubated at $0^{\circ} \mathrm{C}$. The uptake of ${ }^{125}$ I-prolactin by mammary tissues depends on incubation temperature. Radioactivity uptake by tissues was highest at $37^{\circ} \mathrm{C}$ and lowest at $0^{\circ} \mathrm{C}$ (Fig. 3). Tissues incubated at $37^{\circ} \mathrm{C}$ for 30 or 120 minutes with $5 \mu \mathrm{g} / \mathrm{m} l$ of native prolactin and $6 \mathrm{ng} / \mathrm{m} l$ of ${ }^{125} \mathrm{I}$ prolactin showed significantly lower uptake of radioactivity than those without native prolactin at the same temperature. The uptake by the tissue with native prolactin at $37^{\circ} \mathrm{C}$ was comparable to the uptake by the tissue without native prolactin at $0^{\circ} \mathrm{C}$.

Mammary tissues preincubated with 6 $\mathrm{ng} / \mathrm{ml}$ of ${ }^{125} \mathrm{I}$-prolactin for 60 minutes at $37^{\circ} \mathrm{C}$ released $30 \%$ and $49 \%$ of radioactivity during 60 minutes of incubation at $25^{\circ} \mathrm{C}$ and $37^{\circ} \mathrm{C}$, respectively. At $0^{\circ} \mathrm{C}$, however, radioactivity was low in the medium. Released radioactivity was highest $(49 \%)$ at $37^{\circ} \mathrm{C}$ and lowest $(11 \%)$ at $0^{\circ} \mathrm{C}$ (Fig. 4). Release of radioactivity from tissues also depended on temperature. Fig. 5 illustrates radioactivity released from tissues which were preincubated with ${ }^{125}$ I-prolactin at $37^{\circ} \mathrm{C}$ for 60 minutes and then transferred to the medium containing $0,6 \mathrm{ng} / \mathrm{m} l$ or $1.25 \mu \mathrm{g} / \mathrm{m} l$ of native prolactin for another 60 -minute incubation. The concentration of prolactin in media did not significantly affect the amount of radioactivity released.

To examine nonspecific uptake and release of radioactive protein by tissues, ${ }^{131} \mathrm{I}$ human serum albumin was used. Radioactivity uptake was affected by temperature during early stage of incubation, indicating a difference of diffusion speed by temperature. Tissues incubated for 15 minutes had the highest radioactivity at $37^{\circ} \mathrm{C}$ and the 


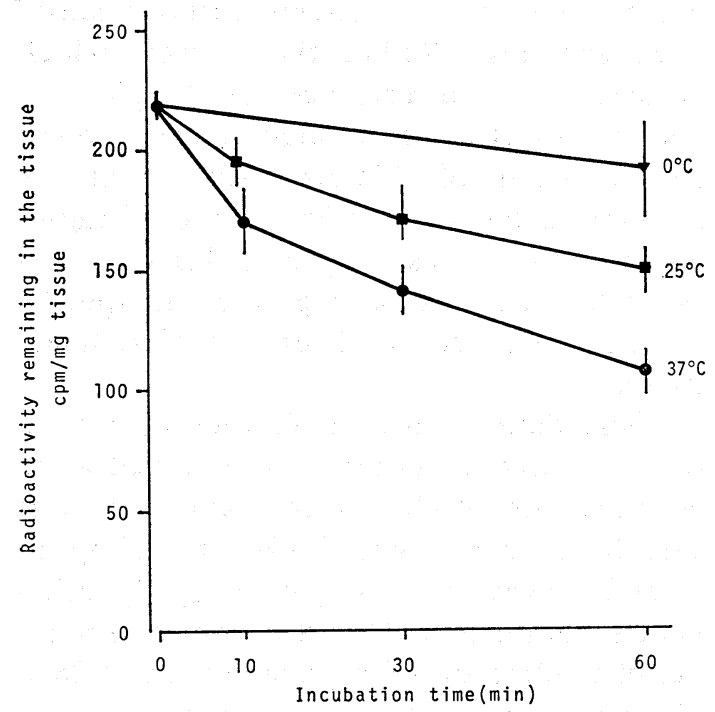

Fig. 4. Influence of incubation time and temperature on release of ${ }^{125} \mathrm{I}$-prolactin from mammary tissues preincubated with $6 \mathrm{ng} / \mathrm{ml}$ of ${ }^{125} \mathrm{I}$-prolactin for 60 minutes. The bars show standard errors of six experiments.

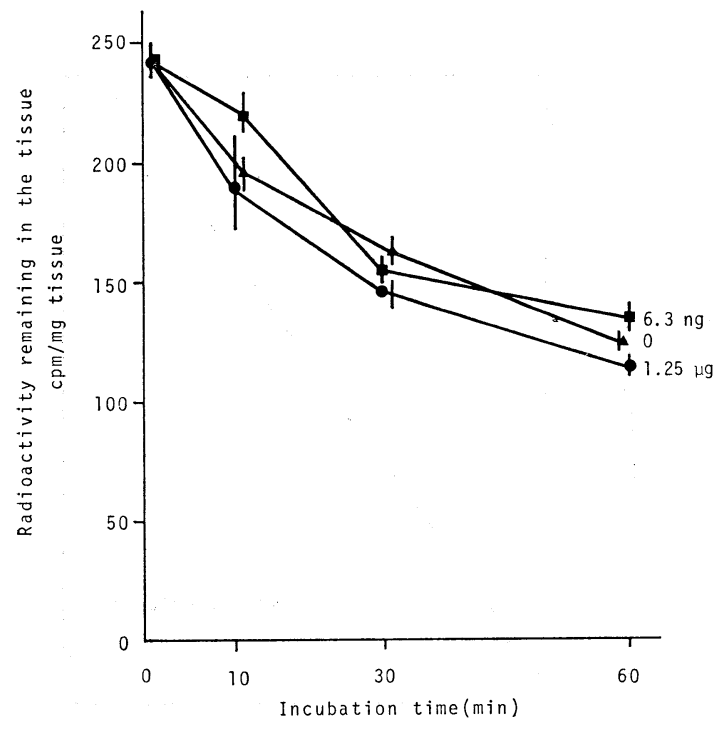

Fig. 5. Influence of prolactin concentration on radioactivity release from mammary tissues preincubated with $6 \mathrm{ng} / \mathrm{ml}$ of ${ }^{125} \mathrm{I}$-prolactin for 60 minutes at $37^{\circ} \mathrm{C}$. The bars show standard errors of six experiments.

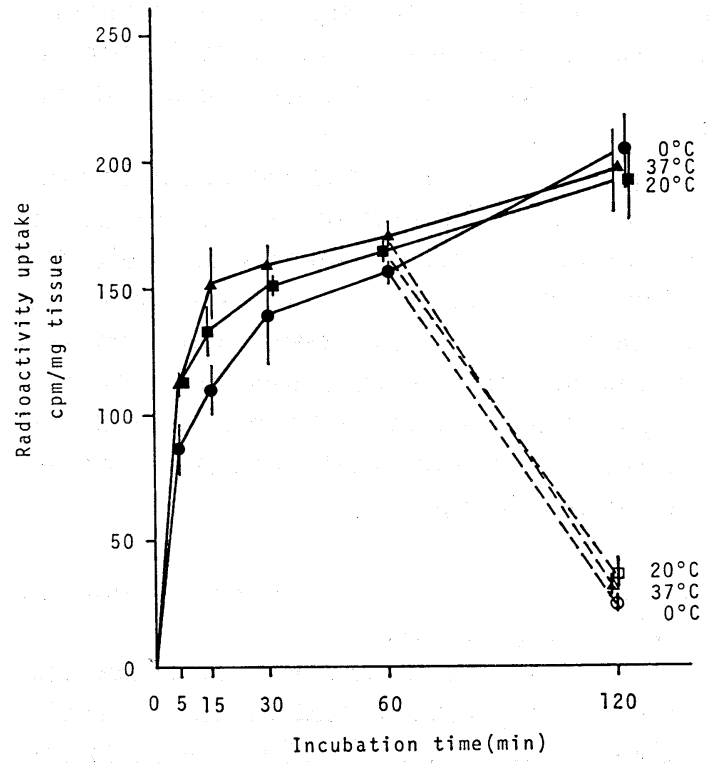

Fig. 6. Time course and influence of temperature on the uptake of ${ }^{131}$ I-HSA by mammary tissues incubated at 0,20 and $37^{\circ} \mathrm{C}$. The broken lines show radioactivity remaining in tissues incubated for 60 minutes after 60 minutes of preincubation with ${ }^{131} \mathrm{I}-\mathrm{HSA}$ at the same temperature. The bars show standard errors of six experiments.

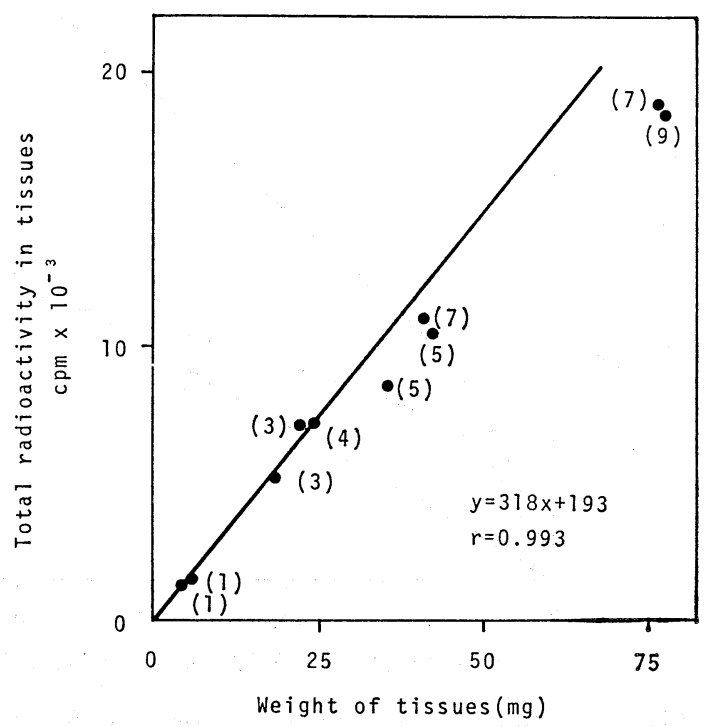

Fig. 7. Effect of amount of tissue on total uptake of radioactivity during incubation for 120 minutes at $37^{\circ} \mathrm{C}$. Figures in parentheses represent number of tissue slices. The regression line is based on tissues below $30 \mathrm{mg}$ of total weight. 
lowest at $0^{\circ} \mathrm{C}$. No significant difference of radioactivity was observed at 30 minutes or later. Apparently temperature did not influence release (Fig. 6).

Figure 7 illustrates increase of total radioactivity of ${ }^{125} \mathrm{I}$-prolactin in the tissues as the amount of tissues increased, while the volume of incubation medium remained constant $(1.5 \mathrm{~m} l)$. Regression equation was calculated with tissues below $30 \mathrm{mg}$ of total weight, since radioactivity per weight decreased when the total weight of tissues was above $30 \mathrm{mg}$.

Effect of ${ }^{125}$ I-prolactin concentration on radioactivity uptake

Relationship between various concentrations of ${ }^{125}$ I-prolactin and uptake of radioactivity is illustrated in Fig. 8 using lactating mice whose litters were removed 6

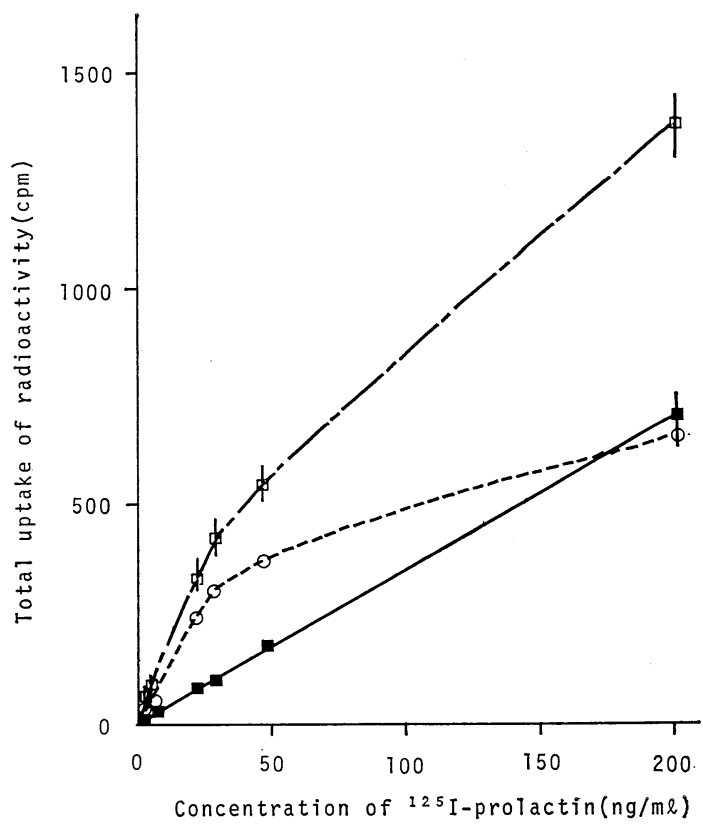

Fig. 8. Binding as a function of concentration of ${ }^{125}$ I-prolactin. The broken line shows specific binding (O---O). The correction was made by subtracting nonspecific uptake ( - - $\mathbf{\square})$ from total uptake $(\square-\cdot-\square)$. The bars show standard errors of six experiments. hours prior to experiments without subsequent suckling. Radioactivity uptake which occurred in the presence of $5 \mu \mathrm{g} / \mathrm{m} l$ of native prolactin was related linearly to the concentration of ${ }^{125} \mathrm{I}$-prolactin. This is thought to be nonspecific uptake of radioactivity by tissues. Specific binding was estimated by subtracting the nonspecific uptake from the total uptake of radioactivity.

These data seemed to fit reversible reaction of second order. The dissociation constant (or Michaelis constant, $\mathrm{Km}$ ) was calculated to be $1.4 \times 10^{-9} \mathrm{M}$ or $33.3 \mathrm{ng} / \mathrm{m} l$ from Lineweaver-Burk plot (Fig. 9) using values obtained in Fig. 8. The total number of binding sites for prolactin was $1.38 \times$ $10^{-15} \mathrm{~mole} / \mathrm{mg}$ wet weight of tissue from Lineweaver-Burk plot.

Specificity of the receptor for prolactins

Specificity of the interaction was examined by incubating mammary tissues with $6 \mathrm{ng} / \mathrm{m} l$ of ${ }^{125} \mathrm{I}$-prolactin in the presence of various doses of several hormones. Ovine

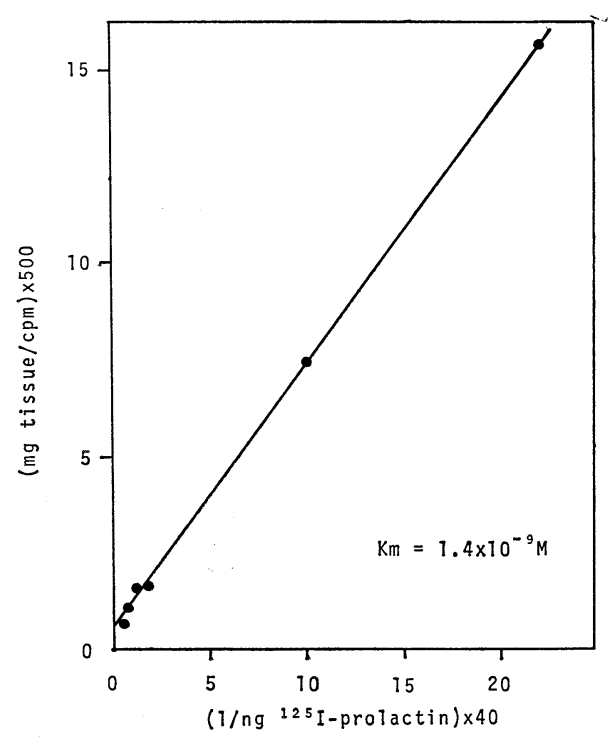

Fig. 9. Lineweaver-Burk plot for specific binding of ${ }^{125}$ I-prolactin. The reciprocal of specific binding in Fig. 8 was plotted on the ordinate. 
prolactin, human growth hormone (hGH) and human placental lactogen (hPL) displaced ${ }^{125}$ I-prolactin and dose response curves were all parallel. One $\mathrm{ng} / \mathrm{m} l$ of ovine prolactin, $5 \mathrm{ng} / \mathrm{m} l$ of $\mathrm{hGH}$ and 10 $\mathrm{ng} / \mathrm{m} l$ of hPL slightly displaced ${ }^{125} \mathrm{I}$-prolactin. Bovine GH and bACTH showed slight competition at high doses. Bovine insulin, bTSH, oLH, pregnant mare serum gonadotropin (PMS) and hCG did not affect the binding of ${ }^{125} \mathrm{I}$-prolactin. The Michaelis constant $(\mathrm{Km})$ was estimated to be $1.2 \times$ $10^{-9} \mathrm{M}$ or $28 \mathrm{ng} / \mathrm{m} l$ from the mid-value of the dose response curve of ovine prolactin. This was similar to that from LineweaverBurk plot.

\section{Discussion}

The original procedure of iodination by Frantz and Turkington (1972) was slightly modified by decreasing the total amount of hydrogen peroxide to avoid oxidation of prolactin. The prolactin iodinated in this way seems to be immunologically and bio-

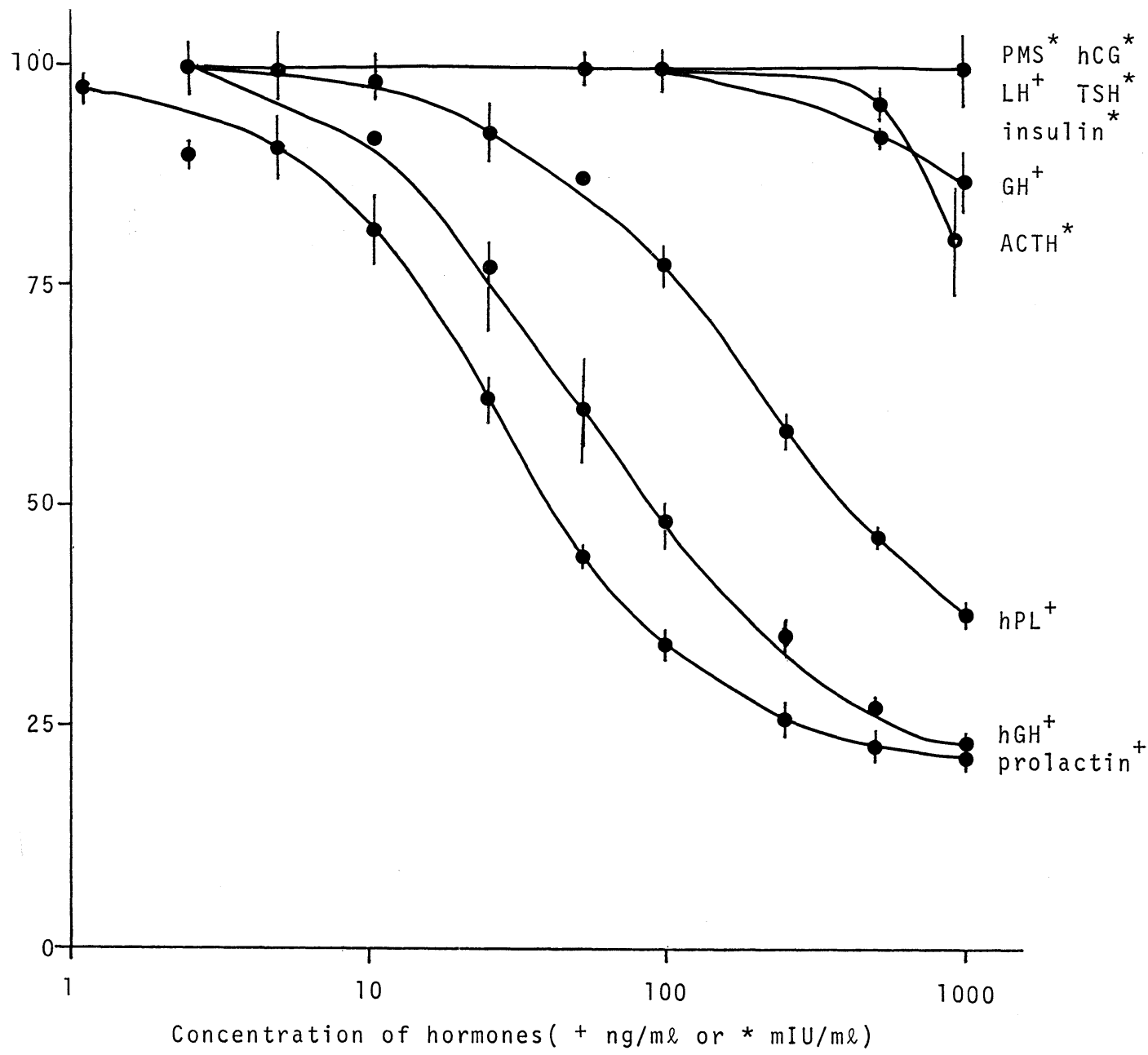

Fig. 10. Displacement of ${ }^{125}$ I-prolactin with various hormones at various concentrations. 
logically intact, and showed only one radioactive peak by disc electrophoresis, whereas Frantz and Turkington observed two radioactive peaks. Our preparation of prolactin had high enough specific activity for receptor studies.

The uptake of iodinated prolactin was significantly inhibited to $22 \%$ by addition of relatively large amount of native pro1actin. Nonspecific diffusion does not explain this observation, because the concentration of radioactivity was the same in both media. The difference of prolactin uptake could be caused by inhibition of special accumulation of radioactivity surpassing the amount of usual diffusion or by suppression of diffusion. The volume of extracellular space in lactating mammary tissues was estimated to be $35 \%$ or 0.35 $\mu \mathrm{l} / \mathrm{mg}$ tissue using ${ }^{131} \mathrm{I}$-HSA. There was a linear relation between concentration of ${ }^{125} \mathrm{I}$-prolactin and radioactivity uptake in the presence of $5 \mu \mathrm{g} / \mathrm{m} l$ of native prolactin, which suggests that this uptake was mainly nonspecific. The extracellular space volume was also calculated assuming that radioactivity uptake in the presence of native prolactin was nonspecific. This value $(39 \%$ or $0.39 \mu \mathrm{l} / \mathrm{mg}$ tissue) was in good agreement with the figure estimated using ${ }^{131} \mathrm{I}-$ HSA related above. It is concluded that the lower uptake of iodinated prolactin was caused by inhibition of special accumulation rather than by suppression of diffusion. Considering that no other hormones inhibit this special accumulation that human growth hormone and human placental lactogen both of which are lactogenic (Frantz and Kleinberg, 1970; Turkington and Topper, 1966 ; Loewenstein et al., 1971 ; Turkington, 1971), we conclude that this accumulation was specific binding of prolactin.

To study this specific binding further, we postulated a bimolecular reversible reaction model, [prolactin] + [receptor] $\rightleftarrows$ [prolactinreceptor complex]. This model fits the behavior of radioactive prolactin, especially time-dependent feature of uptake, relationship between radioactivity uptake and weight of tissues, and relationship between radioactivity uptake and concentration of ${ }^{125}$ I-prolactin. Shiu and Friesen (1974) also found that their data fit a reversible second order reaction. The low Michaelis constant (dissociation constant) shows high affinity of prolactin to its receptors, in good agreement with the constants obtained by Frantz et al., (1974) and Shiu and Friesen (1974).

The displacement caused by high dose of ACTH and GH is thought to be due to contamination with prolactin (Shiu et al., 1973; Johke, unpublished data). It is interesting to note that $\mathrm{GH}$ did not displace prolactin though mammary glands of this strain of mice are stimulated to secretion by $\mathrm{GH}$ in organ culture (Kobayashi et al., 1969; Ito et al., 1970) as in some other strains of mice (Nandi, 1961; Rivera, 1964). We suppose that GH has its own binding site in mouse mammary glands different from prolactin receptors and that these two hormones do not share their binding sites.

\section{Acknowledgement}

We are grateful to Dr. Motoo Naito, Professor of Animal Breeding at the University of Tokyo, and Dr. Yoshisuke Suzuki, Professor of Veterinary Physiology at the University of Tokyo, both of whom read the manuscript and gave useful suggestions, to Mr. Yoichi Shoda, Associate Professor of Animal Breeding at the University of Tokyo, for his help on the pigeon-crop assays, and to Dr. Atsushi Takagi at Dainabot Radioisotope Laboratory for giving us samples of human growth hormone and human placental lactogen which came originally from the $\mathrm{Na}$ tional Institutes of Health, U.S.A.

\section{References}

Bralla, V. K. and L. E. Reichert, Jr. (1974). J. Biol. Chem. 249, 43.

Catt, K. J., T. Tsuruhara and M. L. Dufau (1972). Biochim. Biophys. Acta 279, 194. 
Cowie, A. T. and J. S. Tindal (1971). The physiology of Lactation, Edward Arnold Ltd., London.

Frantz, A. G. and D. L. Kleinberg (1970). Science 170, 745.

Frantz, W. L., J. H. MacIndoe and R. W. Turkington (1974). J. Endocr. 60, 485.

Frantz, W. L. and R. W. Turkington (1972). Endocrinology 91, 1545.

Greenwood, F. S., W. M. Hunter and J. S. Glover (1963). Biochem. J. 89, 114.

Ito, I., H. Kobayashi and M. Naito (1970). Jap. J. Zootech. Sci. 41 (Suppl.) 46. (in Japanese)

Johke, T. (1969). Endocrinol. Japon. 16, 581.

Kobayashi, H., I. Ito and M. Naito (1969). Jap. J. Zootech. Sci. 40 (Suppl.) 27. (in Japanese)

Lee, C. T. and R. J. Ryan (1971). Endocrinology 89, 1515.
Loewenstein, J. E., I. K. Mariz, G. T. Peake and W. H. Daughaday (1971). J. Clin. Endocrin. 33, 217.

Nandi, S. (1961). Proc. Soc. Exp. Biol. Med. 108, 1.

Rivera, E. M. (1964). Endocrinology 74, 853.

Shiu, R. P. C. and H. G. Friesen (1974). Biochem. J. 140, 301.

Shiu, R. P. C., P. A. Kelly and H. G. Friesen (1973). Science 180, 968.

Tanabe, Y., Y. Shoda and Y. Saeki (1954). Bull. Nat. Inst. Agr. Sci. (Series G) 9, 57. (in Japanese)

Turkington, R. W. (1970). Biochem. Biophys. Res. Comm. 41, 1362.

Turkington, R. W. (1971). J. Clin. Endocrin. 33, 210.

Turkington, R. W. and Y. J. Topper (1966). Endocrinology 79, 175. 